\title{
Transamination and Oxidative Decarboxylation Rates of Branched-Chain 2-Oxo Acids in Cultured Human Skin Fibroblasts
}

\author{
PETER SCHADEWALDT, WOLFGANG RADECK, HANS-WERNER HAMMEN, AND \\ UDO WENDEL \\ Institut für Physiologische Chemie II [P.S., W.R., H-W.H.] and Kinderklinik C [U.W.], Universität Düsseldorf, \\ Moorenstr. 5, D-4000 Düsseldorf, FRG
}

\begin{abstract}
Transamination and oxidative decarboxylation of branched-chain $\mathrm{L}$-amino acid derived 2-oxo acids in cultured human skin fibroblasts from normal subjects and from a patient with maple syrup urine disease (variant form) were comparatively studied in incubations with 1${ }^{14} \mathrm{C}$-labeled substrates $(1 \mathrm{mmol} / \mathrm{liter})$. With normal cells, ${ }^{14} \mathrm{CO}_{2}$ release ranged from about 11 to $3 \mathrm{nmol} / 90 \mathrm{~min} / \mathrm{mg}$ of cell protein in the order 3-methyl-2-oxo[ $\left.{ }^{14} \mathrm{C}\right]$ butanoate $>$ (S)-3-methyl-2-oxo $\left[{ }^{14}\right.$ Clpentanoate $>$ 4-methyl-2oxo $\left[{ }^{14}\right.$ Clpentanoate $>(\mathrm{R})-3$-methyl-2-oxo $\left[{ }^{14} \mathrm{C}\right]$ pentanoate. Formation of the corresponding branched-chain amino $\left[{ }^{14} \mathrm{C}\right]$ acids was substantially higher than ${ }^{14} \mathrm{CO}_{2}$ production (around 10-fold) and similar with $\mathrm{L}$-valine, L-isoleucine, and L-leucine. L-Allo-isoleucine production [from (R)-3methyl-2-oxopentanoate] was significantly lower. With maple syrup urine disease fibroblasts, comparable transamination rates were observed. Related to the findings with normal cells, ${ }^{14} \mathrm{CO}_{2}$ release from each substrate was differently reduced and apparent residual branched-chain 2-oxo acid dehydrogenase complex activity with 3-methyl-2-oxobutanoate, 4-methyl-2-oxopentanoate, (S)-, and (R)-3methyl-2-oxopentanoate amounted to $12,13,22$, and $50 \%$, respectively. (Pediatr Res 23: 40-44, 1988)
\end{abstract}

\section{Abbreviations}

MSUD, maple syrup urine disease

HPLC, high-performance liquid chromatography

PBS, phosphate-buffered saline

In MSUD, the oxidative decarboxylation of branched-chain 2-oxo acids is impaired by a deficiency in branched-chain 2-oxo acid dehydrogenase activity (EC 1.2.4.4). Due to the metabolic block and normal aminotransferase activities, branched-chain amino as well as the corresponding 2-oxo acids accumulate in MSUD (1-3). (S)-3-methyl-2-oxopentanoate, the transamination product of $\mathrm{L}$-isoleucine, can undergo racemization in vivo $(4,5)$. The main metabolic fate of (R)-3-methyl-2-oxopentanoate thus formed appears to be transamination to $\mathrm{L}$-allo-isoleucine which is regularly found in the patients blood (6-10).

In most studies on kinetics and regulation of branched-chain 2-oxo acid metabolism in human tissues, e.g. with homogenates of heart and skeletal muscle (11), mitochondrial preparations (12), and cultured intact and broken cells (13-15), only 2-oxo

Received May 29, 1987; accepted September 1, 1987.

Correspondence Dr. Peter Schadewaldt, Institut für Physiologische Chemie II, Universität Düsseldorf, Moorenstr. 5, D-4000 Düsseldorf, West Germany. Supported by Grant We 614/6-1 from the Deutsche Forschungsgemeinschaft. acids derived from L-leucine and/or L-valine have been used as substrates. In few studies, (S)- or unspecified (R,S)-3-methyl-2oxopentanoate have been used as well (16-19). However, (R)-3methyl-2-oxopentanoate metabolism has not been examined.

The aim of the present study was to get further insight into Lallo-isoleucine metabolism in man. We therefore studied 1) oxidative decarboxylation rates of all four branched-chain 2-oxo acids in intact skin fibroblasts derived from normal subjects and from a patient with variant MSUD and 2) 2-oxo acid transamination, since amination of (R)-3-methyl-2-oxopentanoate is the only way for L-allo-isoleucine formation in vivo.

\section{MATERIALS AND METHODS}

Chemicals. $\mathrm{L}-\left[1-{ }^{14} \mathrm{C}\right]$ leucine $(2.1 \mathrm{GBq} / \mathrm{mmol}), \mathrm{L}-\left[1-{ }^{14} \mathrm{C}\right]$ valine $(2.0 \mathrm{GBq} / \mathrm{mmol})$, and sodium $\left[1-{ }^{14} \mathrm{C}\right]$ pyruvate $(340 \mathrm{MBq} / \mathrm{mmol})$ were from New England Nuclear, Dreieich, $\mathrm{K}^{14} \mathrm{CN}(370 \mathrm{MBq} /$ mmol), $\mathrm{NaH}^{14} \mathrm{CO}_{3}(2.1 \mathrm{GBq} / \mathrm{mmol})$, and [methyl- ${ }^{14} \mathrm{C}$ ] toluene standard were obtained from Amersham-Buchler,Braunschweig. Enzymes and coenzymes were from Boehringer, Mannheim, Acylase I (EC 3.5.1.14) was from Sigma, Deisenhofen, and Dowex 50 WX8 (50-100 mesh) from Serva, Heidelberg. All other chemicals were purchased in the highest available purity from Merck, Darmstadt, or Sigma. Purity of branched-chain 2oxo acids was checked by automatic amino acid analysis and by a modification of the HPLC method described previously (20). A Nucleosil $5 \mathrm{C}_{18}$ column $(250 \times 4 \mathrm{~mm}$, Macherey-Nagel, Düren, guard column Lichrosorb RP-18, $4 \times 4 \mathrm{~mm}$, Merck) and $33 \%$ $\mathrm{CH}_{3} \mathrm{CN}$ at $1.3 \mathrm{ml} / \mathrm{min}$ were used. The respective quinoxalinol derivatives were prepared as described previously (21). Purity was as specified by the suppliers. Unlabeled racemic (R,S)-3methyl-2-oxopentanoate was optically inactive.

Branched-chain 2-oxo acids. 2-oxo acids from $\mathrm{L}-\left[1{ }^{14} \mathrm{C}\right]$ leucine and $\mathrm{L}-\left[1-{ }^{14} \mathrm{C}\right]$ valine were prepared as described previously (22). 1- ${ }^{14} \mathrm{C}$-labeled (S)- (14.1 MBq/mmol) and (R)-3-methyl-2-oxopentanoate $(9.2 \mathrm{MBq} / \mathrm{mmol})$ were synthesized from the radioactive labeled $\mathrm{N}$-acetyl derivatives of $\mathrm{D}$-allo-isoleucine and $\mathrm{D}$ isoieucine, respectively $(23,24)$. Purity $(>97 \%)$ and the specific radioactivities of the products were examined by HPLC analysis as described above. Polarimetrically, impurities were not detectable.

Cell culture. Human fibroblasts were obtained from skin biopsies of two normal subjects (strain RE and WE, mixed at equal portions for the assays) and of a patient (strain JA) with a variant form (intermittent type) of MSUD. Cells were multiplied in monolayer culture as described (17). After 10-20 passages, fibroblasts at confluency were harvested by trypsinization, suspended in culture medium, washed twice with $\mathrm{NaCl}$ solution $(0.154 \mathrm{~mol} /$ liter), and resuspended in PBS, Dulbecco's modification (PBS), with bovine serum albumin (1.5 g/liter) and D-glucose $(12.4$ 
mmol/liter). $0.4 \mathrm{ml}$ of a suspension adjusted to about $2 \times 10^{6}$ cells $/ \mathrm{ml}$ was inserted into each assay. Mycoplasma contamination tests (25) were negative.

Incubations. ${ }^{14} \mathrm{CO}_{2}$-tight $22-\mathrm{ml}$ incubation flasks (11) were used to incubate fibroblasts $(0.3-0.5 \mathrm{mg}$ of cell protein) in a final volume of $0.9 \mathrm{ml}$ PBS containing bovine serum albumin $(0.07 \%$, $\mathrm{w} / \mathrm{v})$, D-glucose $(5.5 \mathrm{mmol} / \mathrm{liter})$, and 2 -oxo[ $\left.1-{ }^{14} \mathrm{C}\right]$ acids as indicated. The reaction was started by addition of cell suspension and was stopped by injection of $0.5 \mathrm{ml}$ sulfosalicylic acid $(10 \%$, w/v). In blanks, cells were omitted. All samples were run in duplicate.

Assays. ${ }^{14} \mathrm{CO}_{2}$ released during incubation was completely absorbed in $0.5 \mathrm{ml}$ ethanolamine-ethylenglycol $(1: 2, \mathrm{v} / \mathrm{v})$ and measured by liquid scintillation counting $(11) .{ }^{14} \mathrm{CO}_{2}$ recovery was checked with $\mathrm{NaH}^{14} \mathrm{CO}_{3}$ solutions and counting efficiency by internal standardization with $\left[{ }^{14} \mathrm{C}\right]$ toluene.

For the estimation of free amino acids, $0.1 \mathrm{ml}$ DL-norleucine solution $(0.1 \mathrm{mmol} / \mathrm{liter})$ was then added to the medium and precipitated protein removed by centrifugation. One $\mathrm{ml}$ of the supernatant was freeze-dried and the residue dissolved in $0.5 \mathrm{ml}$ LiOH solution $\left(0.25 \mathrm{~mol} / \mathrm{liter}, 2 \% 2.2^{\prime}\right.$-thiodiethanol, w/v). The concentration of and radioactivity in amino acids were determined on an automatic amino acid analyzer in runs with and without ninhydrin, respectively.

For the determination of ${ }^{14} \mathrm{C}$-radioactivity in acid insoluble material, the precipitate was thoroughly washed $(5 \times 1 \mathrm{ml})$ with $3 \%$ sulfosalicylic acid (w/v), containing all branched-chain amino ( $10 \mathrm{mmol} /$ liter) and 2-oxo acids ( $1 \mathrm{mmol} / \mathrm{liter})$, by sonication and centrifugation and dissolved in $1 \mathrm{ml}$ hydroxide of hyamine $10 \times$ (Packard Instruments, Frankfurt).

Protein concentrations $\left(2.1 \times 10^{6}\right.$ cells were equivalent to 1 mg of cell protein) were estimated by the Lowry procedure (26), using bovine serum albumin as a standard.

Calculations. Metabolic rates were calculated from the appropriate ${ }^{14} \mathrm{CO}_{2}$ liberation on the basis of the specific radioactivity of the $\mathrm{C}_{1}$-atom of the respective 2 -oxo $\left[{ }^{14} \mathrm{C}\right]$ acid in the medium. Results are means $\pm \mathrm{SD}$ of the independent experiments performed on different days. Statistically significant differences were determined by Student's paired $t$ test.

\section{RESULTS}

Time and concentration dependence. In incubations of normal fibroblasts in the absence of 2-oxo acids, free amino acids (with the exception of aspartate) accumulated at gradually enhanced rates. The increase of leucine, valine, and isoleucine during 0 $30 \mathrm{~min}$ of incubation amounted to $2.0 \pm 0.3,2.7 \pm 0.4$, and 0.9 $\pm 0.3 \mathrm{nmol} / \mathrm{mg}$ of cell protein, and during $90-120 \mathrm{~min}$ to $3.7 \pm$ $0.4,3.1 \pm 0.4$, and $1.5 \pm 0.5 \mathrm{nmol} / \mathrm{mg}$ of cell protein, respectively.

The time course of leucine accumulation in incubations with 4-methyl-2-oxopentanoate ( $1 \mathrm{mmol} / \mathrm{liter})$ is shown in Figure 1. The rate of formation declined up to 30 min of incubation and then remained constant up to the end of the experiment. With the other three branched-chain 2-oxo acids, comparable effects on the accumulation of the corresponding branched-chain amino acids were found (data not shown).

The ${ }^{14} \mathrm{CO}_{2}$ release in incubations with $1-{ }^{14} \mathrm{C}$-labeled branchedchain 2-oxo acids ( $1 \mathrm{mmol} / \mathrm{liter})$ was linear with time (data not shown). Concentration dependence of oxidative decarboxylation of 2-oxo[ $\left[{ }^{14} \mathrm{C}\right.$ acids $(0.03-2 \mathrm{mmol} / \mathrm{liter})$ was examined in 90 -min incubations. Figure 2 shows that total ${ }^{14} \mathrm{CO}_{2}$ release was enhanced at higher substrate concentrations. Saturating conditions were not reached.

The concentration dependent effect of the branched-chain 2oxo acids on the formation of the corresponding amino acid is shown in Figure 3. The curves exhibited a hyperbolic shape and half maximal effects were obtained at about $0.1 \mathrm{mmol} / \mathrm{liter}$ of 2 oxo acid.

As compared to 2-oxo acid-free incubations of both normal

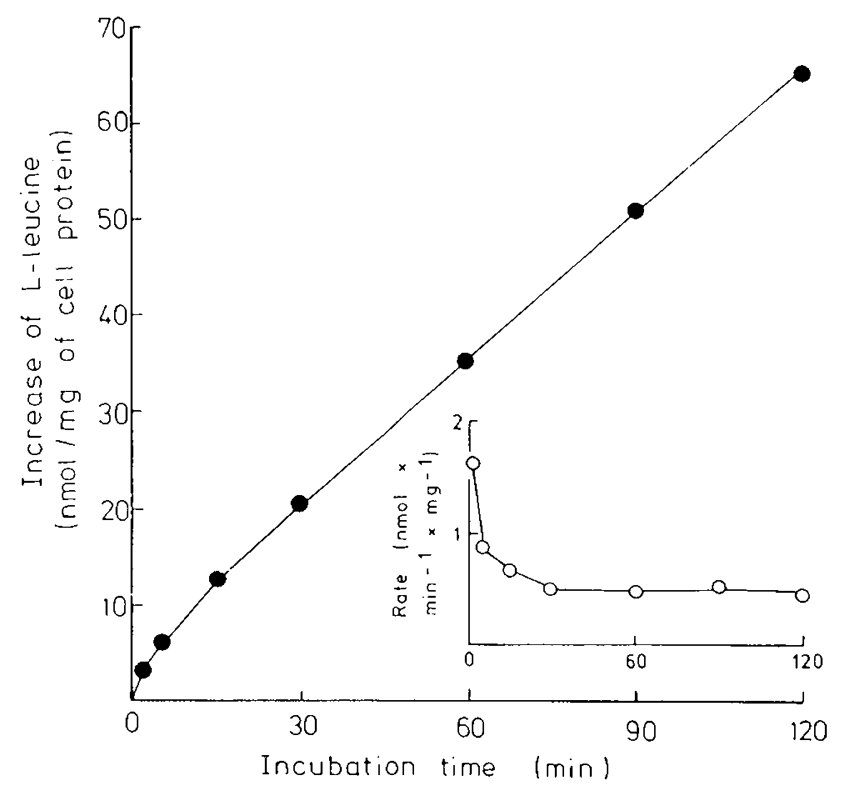

Fig. 1. Time dependence of L-leucine production in incubations of cultured human skin fibroblasts with 4-methyl-2-oxopentanoate (1 $\mathrm{mmol} / \mathrm{liter}$ ). Cells derived from normal subjects were incubated at $37^{\circ} \mathrm{C}$ for 2-120 min. Sample content of free leucine was determined and corrected for the content in appropriate blanks with unincubated cells. In the inset, the rate of leucine production is plotted against the incubation time. The respective rates were calculated from the differences of leucine content and of the min elapsed between two successive incubation times.

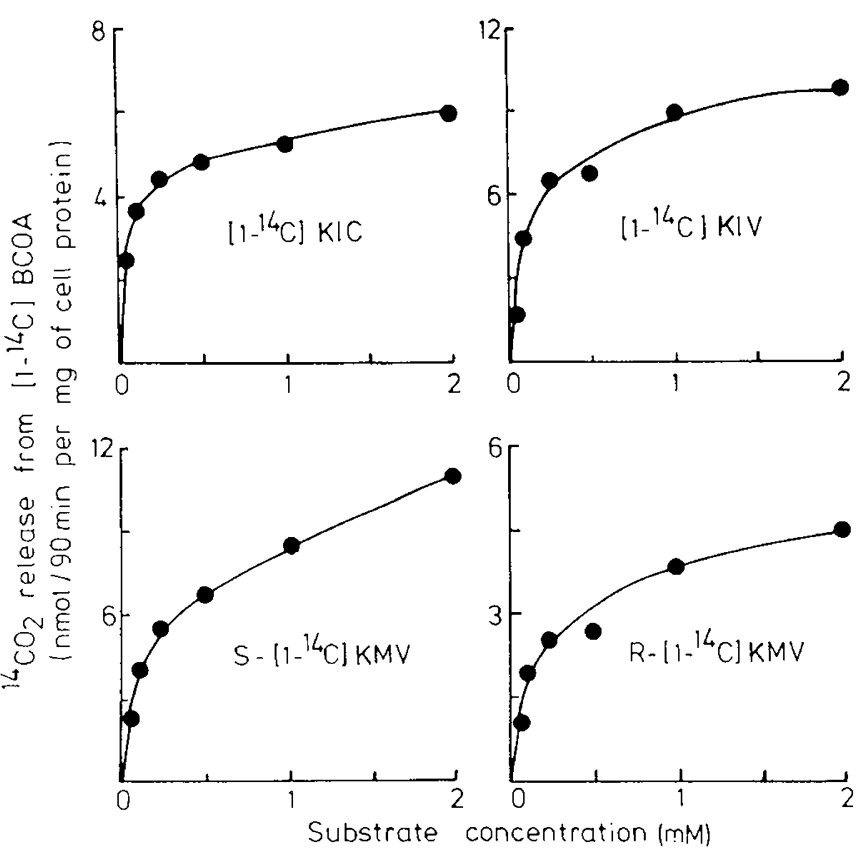

Fig. 2. Concentration dependence of ${ }^{14} \mathrm{CO}_{2}$ release from $1-{ }^{14} \mathrm{C}$-labelled branched-chain 2-oxo acids $(B C O A)$ in cultured human skin fibroblasts derived from normal subjects. Cells were incubated at $37^{\circ} \mathrm{C}$ for $90 \mathrm{~min}$. In incubations with 4-methyl-2-oxopentanoate $(K I C)$ and 3methyl-2-oxobutanoate $(K I V) 25 \mathrm{kBq}$ was added to each sample. The substrate concentration ranged from $0.03 \mathrm{mmol} /$ liter $(0.9 \mathrm{kBq} / \mathrm{nmol})$ to $2 \mathrm{mmol} / \mathrm{liter}(14 \mathrm{~Bq} / \mathrm{nmol})$. In experiments with $(\mathrm{S})-(S-K M V ; 14 \mathrm{~Bq} /$ $\mathrm{nmol})$ and (R)-3-methyl-2-oxopentanoate $(R-K M V ; 9 \mathrm{~Bq} / \mathrm{nmol})$ the specific radioactivity remained constant over the entire concentration range. 


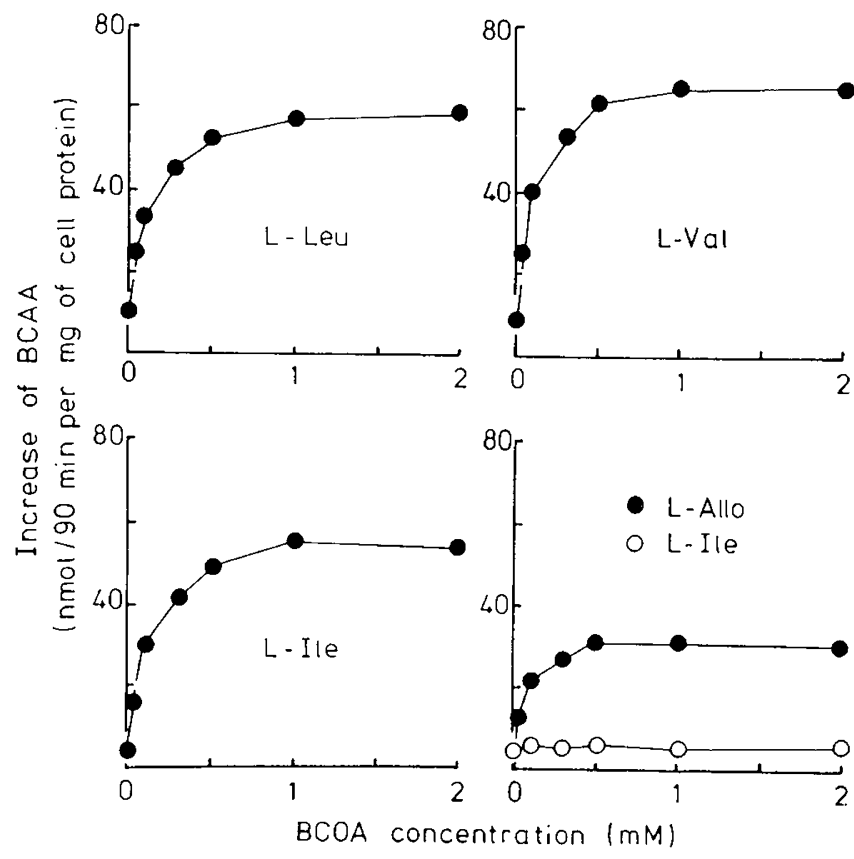

Fig. 3. Concentration dependence of branched-chain amino acid $(B C A A)$ production in incubations of cultured human skin fibroblasts with the corresponding branched-chain 2-oxo acid $(B C O A)$. Cells derived from normal subjects were incubated at $37^{\circ} \mathrm{C}$ for 90 min with $0.03-2$ $\mathrm{mmol} / \mathrm{liter}$ of branched-chain 2-oxo acid ( $c f$. Fig. 2) and the production of the respective amino acid was determined as described in the legend to Figure 1. In the case of incubations with (R)-3-methyl-2-oxopentanoate, the release of L-allo-isoleucine (L-Allo) is compared to that of its isomer $\mathrm{L}$-isoleucine.

and MSUD fibroblasts, an inclusion of pyruvate in the medium had no significant effect on the accumulation of amino acids under standard incubation conditions ( $1 \mathrm{mmol} 2$-oxo acid/liter, $90 \mathrm{~min}$; data not shown). In contrast, when branched-chain 2 oxo acids were added, the accumulation of the corresponding branched-chain amino acid was enhanced. That of most other amino acids was reduced, most distinct with glutamate, alanine, and the respective other branched-chain amino acids (Table 1, data for MSUD cells not shown). The decreased accumulation of the other amino acids balanced the greater part of the additional $\alpha$-amino groups recovered in the respective increased branched-chain amino acid.

In incubations with (S)-3-methyl-2-oxopentanoate, some Lalloisoleucine accumulated $(2.2 \pm 0.7 \mathrm{nmol} / 90 \mathrm{~min} / \mathrm{mg}$ of cell protein, $n=4$ ) amounting to $5 \pm 1 \%$ of L-isoleucine formation. This relative portion was essentially constant and neither dependent on incubation times nor on 2-oxo acid concentrations applied in this study.

Comparison of metabolism. Metabolism of the four branchedchain 2-oxo[ $\left.1-{ }^{14} \mathrm{C}\right]$ acids was studied under standard incubation conditions. The results are presented in Table 2 . With normal cells, ${ }^{14} \mathrm{CO}_{2}$ release from 2 -oxo $\left[{ }^{14} \mathrm{C}\right]$ acids ranged from about 11 to $3 \mathrm{nmol} / 90 \mathrm{~min} / \mathrm{mg}$ of cell protein in the order 3-methyl-2oxobutanoate $>$ (S)-3-methyl-2-oxopentanoate $>$ 4-methyl-2oxopentanoate $>$ (R)-3-methyl-2-oxopentanoate. Oxidative decarboxylation of the latter 2-oxo acid was about $50 \%$ lower than that of its enantiomer.

Formation of the corresponding branched-chain amino $\left[1-{ }^{14} \mathrm{C}\right]$ acids was about 10 -fold higher than ${ }^{14} \mathrm{CO}_{2}$ production. Related to the specific radioactivity of the 2 -oxo acids used $(=100 \%)$, specific radioactivities of the respective ${ }^{14} \mathrm{C}$-labeled amino acids were about $95 \%$. Furthermore, the radioactivity found in acid insoluble material was less than $3 \%$ of that incorporated into free amino acids. Thus, the accumulation of branched-chain
Table 1. Increase of free amino acid content*

\begin{tabular}{|c|c|c|c|c|c|}
\hline \multirow[b]{2}{*}{$\begin{array}{l}\text { L-Amino } \\
\text { acid }\end{array}$} & \multirow[b]{2}{*}{$\begin{array}{c}\text { Control } \\
\text { incubations }\end{array}$} & \multicolumn{4}{|c|}{ CHANGE ON ADDITION OF $1 \mathrm{MM}$} \\
\hline & & \multicolumn{4}{|c|}{ (nmol/90 $\mathrm{min} / \mathrm{mg}$ of cell protein) } \\
\hline $\begin{array}{l}\text { Gluta- } \\
\text { mate }\end{array}$ & $\begin{array}{c}14 \pm 4 \\
(35 \pm 13)\end{array}$ & $-18 \pm 4$ & $-15 \pm 4$ & $-12 \pm 3$ & $-9 \pm 4$ \\
\hline Alanine & $\begin{array}{l}17 \pm 3 \\
(8 \pm 2)\end{array}$ & $-7 \pm 3$ & $-4 \pm 2$ & $-6 \pm 1$ & $-4 \pm 2$ \\
\hline Valine & $\begin{array}{c}8 \pm 1 \\
(7 \pm 2)\end{array}$ & $-7 \pm 2$ & $66 \pm 17$ & $-5 \pm 1$ & $-2 \pm 1$ \\
\hline Isoleucine & $\begin{array}{c}5 \pm 1 \\
(5 \pm 1)\end{array}$ & $-6 \pm 1$ & $-6 \pm 2$ & $44 \pm 9$ & \pm 0 \\
\hline Leucine & $\begin{array}{c}9 \pm 2 \\
(7 \pm 2)\end{array}$ & $59 \pm 19$ & $-10 \pm 2$ & $-9 \pm 2$ & $-5 \pm 1$ \\
\hline
\end{tabular}

* Effect of branched-chain 2-oxo acids on the increase in selected free amino acids during incubation of cultured human skin fibroblasts. Cells derived from normal subjects were incubated at $37^{\circ} \mathrm{C}$ for $90 \mathrm{~min}$ in the absence (control; free amino acid content of unincubated cells in parentheses) and presence of $1 \mathrm{mmol} /$ liter of branched-chain 2-oxo acid (KIC: 4-methyl-2-oxopentanoate; KIV: 3-methyl-2-oxobutanoate; R-, S-KMV: (R)- and (S)-3-methyl-2-oxopentanoate). Control values represent the differences of free amino acid content before and after substrate-free incubation. The other data were calculated from the differences between the free amino acid content in incubations without and with 2-oxo acid, respectively. Results are means $\pm \mathrm{SD}$ from four to seven independent incubations.

amino $\left[{ }^{14} \mathrm{C}\right]$ acids largely equaled transamination of the corresponding 2-oxo[ $\left[{ }^{14} \mathrm{C}\right]$ acid during incubation. No essential differences could be observed between transamination rates of 4methyl-2-oxopentanoate, 3-methyl-2-oxobutanoate, and (S)-3methyl-2-oxopentanoate. However, the production of L-allo$\left[{ }^{14} \mathrm{C}\right]$ isoleucine [from (R)-3-methyl-2-oxo[ $\left[{ }^{14} \mathrm{C}\right]$ pentanoate] was substantially lower and only about one-half of that of $\mathrm{L}-\left[{ }^{14} \mathrm{C}\right]$ isoleucine. These findings are confirmed by incubations with unlabeled racemic (R,S)-3-methyl-2-oxopentanoate $(1 \mathrm{mmol} /$ liter) where the increase of $\mathrm{L}$-isoleucine was significantly higher than that of L-allo-isoleucine ( $35 \pm 7$ versus $20 \pm 6 \mathrm{nmol} / 90$ $\mathrm{min} / \mathrm{mg}$ of cell protein, $n=4, p<0.001)$.

When MSUD fibroblasts were incubated with branched-chain 2-oxo[ $\left.1-{ }^{14} \mathrm{C}\right]$ acids at $1 \mathrm{mmol} / \mathrm{liter}$, the transamination rates corresponded rather well to those observed with normal cells (Table 2). Using (R,S)-3-methyl-2-oxopentanoate, L-isoleucine, and Lallo-isoleucine increased by $30 \pm 11$ and by $14 \pm 5 \mathrm{nmol} / 90$ $\mathrm{min} / \mathrm{mg}$ of cell protein, respectively ( $n=4$; Ile versus allo-Ile: $p$ $<0.02$ ). As expected, ${ }^{14} \mathrm{CO}_{2}$ release was significantly lower than in controls (around $1 \mathrm{nmol} / 90 \mathrm{~min} / \mathrm{mg}$ of cell protein). Moreover, the activity of branched-chain 2-oxo acid dehydrogenase complex seemed to be differently reduced toward each substrate. As compared to the appropriate data obtained with normal cells, residual activity with 4-methyl-2-oxopentanoate, 3-methyl-2-oxobutanoate, (S)-3-methyl-2-oxopentanoate, and (R)-3-methyl-2oxopentanoate amounted to about $13,12,22$, and $50 \%$, respectively.

\section{DISCUSSION}

Using strains of human skin fibroblasts with checked constant metabolic activities, transamination and oxidative decarboxylation rates of the four branched-chain 2-oxo (present study) and amino acids (27) were comparatively studied.

The branched-chain 2-oxo acid concentrations applied in the present experiments have been reported to occur in plasma $(9$ 10). Since rapid transport across the plasma membrane has been demonstrated in cultured human cells $(15,28)$ it seems unlikely that substrate transport into the cells substantially affected measured metabolic rates. On the other hand, net consumption (sum 
Table 2. Metabolism of branched-chain 2-oxo acids*

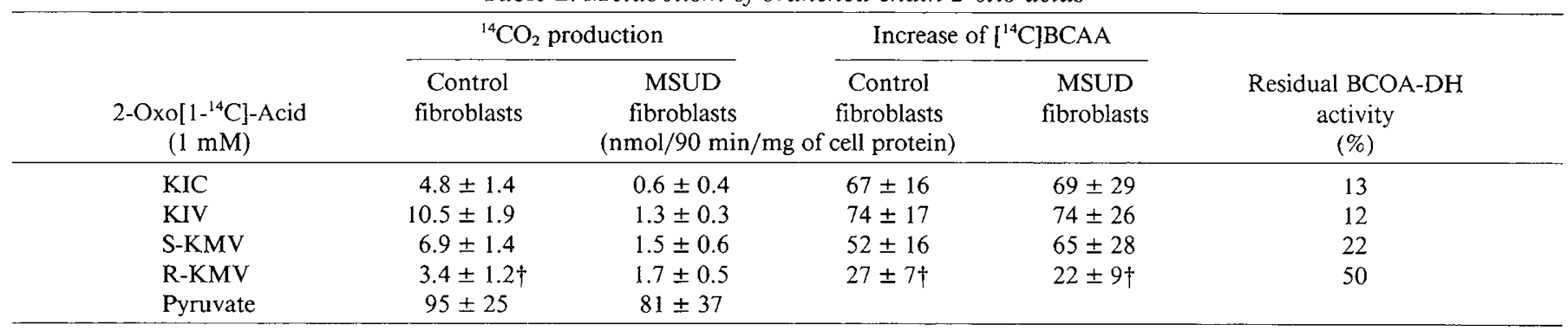

* Metabolism of branched-chain 2-oxo[ $\left[1-{ }^{14} \mathrm{C}\right]$ acids in cultured human skin fibroblasts derived from normal subjects (control) and from a patient with MSUD (variant form). Cells were incubated at $37^{\circ} \mathrm{C}$ for $90 \mathrm{~min}$ with $1 \mathrm{mmol} / \mathrm{liter}$ of $1 \mathrm{-}^{14} \mathrm{C}$-labeled 2-oxo acids (KIC: 4-methyl-2-oxopentanoate, 30-40 Bq/nmol; KIV; 3-methyl-2-oxobutanoate, 25-30 Bq/nmol; S-KMV and R-KMV: (S)-, 14 Bq/nmol, and (R)-3-methyl-2-oxopentanoate, 9 $\mathrm{Bq} / \mathrm{nmol})$. Data from incubations with $\left[1-{ }^{14} \mathrm{C}\right]$ pyruvate $(15-20 \mathrm{~Bq} / \mathrm{nmol})$ are included for comparison. The increase of branched-chain amino acids $\left(\left[{ }^{14} \mathrm{C}\right] \mathrm{BCAA}\right)$ was calculated from the difference of free amino acid content before and after incubation. Residual branched-chain 2-oxo acid dehydrogenase (BCOA-DH) activity in MSUD fibroblasts represents the ${ }^{14} \mathrm{CO}_{2}$ production as related to the respective control value ( $\equiv 100 \%$ ). Results are means \pm SD from four to six independent incubations. Statistically significant differences (paired $t$ test).

$\dagger p<0.005$ versus $S$-KMV

of ${ }^{14} \mathrm{CO}_{2}$ and amino $\left[{ }^{14} \mathrm{C}\right.$-acid formation) amounted maximally to about $25 \%$ of added substrate and isotope exchange between labeled 2-oxo and unlabeled amino acids (cf. Table 1) might have interfered to a varying extent. Thus, metabolic rates appear to represent minimum values when related to the initial substrate concentration in the assays. However, at 2-oxo acid concentrations $\geq 1 \mathrm{mmol} /$ liter, changes in substrate concentration or isotope dilution were of only minor importance.

2-Oxo acid transamination rates decreased in the early phase of incubation. This can be reasonably explained by a relative deficiency of suitable amino group donors within the cells. The decreased formation of other amino acids balanced the greater part of the amino groups found in the accumulating branchedchain amino acid. Similar results have been obtained in loading experiments in vivo $(4,29)$. Whether amino groups were transferred to branched-chain 2-oxo acids solely from glutamate or from other amino acids as well $(3,30)$ remained obscure. At apparently saturating 2-oxo acid concentrations, L-allo-isoleucine formation was about $50 \%$ lower than that of other branchedchain amino acids. The 2-oxo acid concentrations needed for half maximal stimulation was similar for all substrates. These findings suggest that a common branched-chain amino acid aminotransferase operates in human (normal and MSUD) fibroblasts with a similar affinity for all four 2-oxo acids, but a significantly lower capacity for (R)-3-methyl-2-oxopentanoate.

Low amounts of L-allo-isoleucine were formed in incubations of normal and MSUD cells with (S)-3-methyl-2-oxopentanoate. Racemization as a cause is unlikely (31). Rather, some (R)-3methyl-2-oxopentanoate, which is an inevitable by-product of chemically synthesized (S)-enantiomer $(23,24)$, has been introduced into the assays.

In a previous study (27), maximal transamination of branchedchain amino acids $(1 \mathrm{mmol} / \mathrm{liter})$ was in the order L-leucine $>$ L-valine $\geq$ L-isoleucine $>$ L-allo-isoleucine. As related to the backward reaction (present study), transamination rates were considerably lower and amounted to approximately $40 \%$ with leucine and to about $20 \%$ with the other amino acids. For these striking differences between and among branched-chain 2-oxo and amino acids, amino acid transport (32), kinetic properties of the transaminase $(3,30)$, and lack of sufficient amino group acceptors (33) are all likely causes. Their respective contributions to the overall process are unclear at present.

The results provide direct experimental evidence that branched-chain amino acid formation is kinetically greatly favoured over 2-oxo acid production in intact cells. This can explain the rather similar deamination and reamination rates of leucine and valine found in a study with healthy men (despite the about 10-fold excess of amino acids in serum) (34). The substantially lower transamination of (R)-3-methyl-2-oxopentanoate and L-allo-isoleucine seems to share the mechanisms responsible for the delayed appearance and/or disappearance of $\mathrm{L}$-allo-isoleucine in MSUD after an increase of plasma L-isoleucine levels or a L-allo-isoleucine load $(7,35,36)$.

${ }^{14} \mathrm{CO}_{2}$ production from 2 -oxo $\left[{ }^{14} \mathrm{C}\right]$ acids was not saturable at the concentrations used in the present experiments. This is in accordance with a variety of other studies and has been discussed extensively $(13,17,37)$

At $1 \mathrm{mmol} /$ liter of substrate, the rate of 2-oxo acid oxidation was only somewhat higher when cells were exposed to 2-oxo acids than when exposed to the respective amino acids. However, when the concentration of branched-chain 2-oxo acid in the assays is taken into account there was a surprising difference between decarboxylation of the two kinds of substrates. In incubations with branched-chain amino acids $(1 \mathrm{mmol} / \mathrm{liter})$ the respective 2-oxo acids accumulated up to $10 \mu \mathrm{mol} / \mathrm{liter}(27)$. That is two orders of magnitudes lower than the standard 2-oxo acid concentration applied in the present study. This indicates that intracellularly formed 2 -oxo acids are more readily decarboxylated than when added extraneously. Similar conflicting results have been obtained with the perfused rat kidney (38) and hindlimb (Schadewaldt P, Radeck W, unpublished results). Whether a preferred oxidative decarboxylation of 2-oxo acids produced by intramitochondrial transamination of branchedchain amino acids may explain these findings, remains to be investigated.

The relative decarboxylation rates of all four naturally occurring branched-chain 2-oxo acids in intact human fibroblasts was established [3-methyl-2-oxobutanoate $>$ (S)-3-methyl-2-oxopentanoate $>4$-methyl-2-oxopentanoate $>(\mathrm{R})$-3-methyl-2-oxopentanoate]. So far, the same graded oxidation rate has been demonstrated only for the first three substrates in experiments with purified branched-chain 2-oxo acid dehydrogenase complex (39$41)$ and with mitochondrial preparations from human tissue (12, 19).

It is evident from the data in Table 2 that the mutation of the specific MSUD cell line under investigation differentially impaired the activity of the branched-chain 2-oxo acid complex toward the four 2-oxo acid substrates. Exactly the same pattern of residual activity was observed in a previous study with the respective branched-chain amino acids as substrates (27). Differentially impaired decarboxylation activity in a MSUD cell line has been reported by Elsas et al. (16) whereas Dancis et al. (1) found that the residual activity in a number of MSUD cell lines was concurrently reduced against the different branched-chain amino acids tested. Further studies with several MSUD strains (intermittent type) are now in progress to evaluate whether a 
differential impairment of decarboxylation activity is a more general phenomenon in variant MSUD.

\section{REFERENCES}

1. Dancis J, Hutzler J, Snyderman SE, Cox RP 1972 Enzyme activity in classical and variant forms of maple syrup urine disease. J Pediatr 81:312-320

2. Tanaka K, Rosenberg LE 1983 Disorders of branched-chain amino acid and organic acid metabolism. In: Stanbury JB, Wyngaarden JB, Frederickson DS, Goldstein JL, Brown MK (eds) The Metabolic Basis of Inherited Disease, 5 th ed. McGraw-Hill, New York, pp 440-457

3. Ichiara N, Noda C, Tanaka K 1981 Oxidation of branched chain amino acids with special reference to their transaminase. In: Walser M, Williamson JR (eds) Metabolism and Clinical Implications of Branched Chain Amino and Ketoacids. Elsevier/North-Holland, New York, pp 227-231

4. Weinberg RB, Walser M 1977 Racemization and amination of keto-analogue of isoleucine in intact dogs. Biochem Med 17:164-172

5. Matthews DE, Ben-Galim E, Haymond MW, Bier DM 1980 Allo-isoleucine formation in maple syrup urine disease: isotopic evidence for the mechanism. Pediatr Res 14:854-857

6. Mamer OA, Tjoa SS, Scriver CR, Klassen GA 1976 Demonstration of a new mammalian isoleucine catabolic pathway yielding an $\mathrm{R}$ series of metabolites. Biochem J 160:417-426

7. Snyderman SE, Norton PM, Roitman E, Holt LE 1964 Maple syrup urine disease, with particular reference to dietotherapy. Pediatrics 34:454-472

8. Halpern B, Pollok GE 1970 The configuration of alloisoleucine present in maple syrup urine disease plasma. Biochem Med 4:352-356

9. Langenbeck U, Wendel U, Mench-Hoinowski A, Kuschel O, Becker K, Przyrembel H, Bremer HJ 1978 Correlations between branched-chain amino acids and branched-chain $\alpha$-keto acids in blood in maple syrup urine disease. Clin Chim Acta 88:283-291

10. Snyderman SE, Goldstein F, Sansarica C, Norton PM 1984 The relationship between the branched chain amino acids and their $\alpha$-ketoacids in maple syrup urine disease. Pediatr Res 18:851-853

11. Wagenmakers AJM, Veerkamp JH 1982 Degradation of branched-chain amino acids and derived 2-oxo acids in human and rat heart and skeletal muscle. Biochem Med 28:16-31

12. Danner DJ, Wheeler FB, Lemmon SK, Elsas LJ 1978 In vivo and in vitro response of human branched chain $\alpha$-ketoacid dehydrogenase to thiamine and thiamine pyrophosphate. Pediatr Res 12:235-238

13. Dancis J, Hutzler J, Cox RP 1977 Maple syrup urine disease: branched-chain keto acid decarboxylation in fibroblasts as measured with amino acids and keto acids. Am J Hum Genet 29:272-279

14. Chuang DT, Ku LS, Cox RP 1982 Thiamine-responsive maple-syrup urine disease: decreased affinity of the mutant branched-chain $\alpha$-keto acid dehydrogenase for $\alpha$-ketoisovalerate and thiamine pyrophosphate. Proc Natl Acad Sci USA 79:3300-3304

15. Tarpey MM, Willis RC, Seegmiller JE 1977 Uptake of $\alpha$-ketoisocaproic acid in lymphoblast line WI-L2. Biochem Biophys Res Commun 76:1267-1275

16. Elsas LJ, Priest JH, Wheeler FB, Danner DJ, Pask BA 1974 Maple syrup urine disease: coenzyme function and prenatal monitoring. Metabolism 23:569579

17. Wendel U, Wentrup H, Rüdiger HW 1975 Maple syrup urine disease: analysis of branched-chain keto acid decarboxylation in cultured fibroblasts. Pediatr Res 9:709-717

18. Danner DJ, Elsas LJ 1975 Subcellular distribution and cofactor function of human branched chain $\alpha$-ketoacid dehydrogenase in normal and mutant cultured skin fibroblasts. Biochem Med 13:7-22
19. Danner DJ, Davidson ED, Elsas LJ 1975 Thiamine increases the specific activity of human liver branched chain $\alpha$-ketoacid dehydrogenase. Nature 254:529-530

20. Koike K, Koike M 1984 Fluorescent analysis of 2-keto acids in serum and urine by high performance liquid chromatography. Anal Biochem 141:481487

21. Schadewaldt P, Oelers R, Radeck W, Staib W 1984 Oxidative determination of ${ }^{14} \mathrm{C}$-labelled 2-oxo acids. Anal Biochem 143:449-457

22. Rüdiger HW, Langenbeck U, Goedde HW 1972 A simplified method for the preparation of ${ }^{14} \mathrm{C}$-labelled branched chain $\alpha$-oxoacids. Biochem J 126:445446

23. Greenstein JP, Levintow L, Baker CG, White J 1951 Preparation of the four stereoisomers of isoleucine. J Biol Chem 188:647-663

24. Loftfield RB, Eigner EA 1966 The preparation of pure $1-{ }^{14} \mathrm{C}$ - and $1-{ }^{3} \mathrm{H}$-labelled L-amino acids. Biochim Biophys Acta 130:449-457

25. Chen TR 1977 In situ detection of mycoplasma contamination in cell cultures by fluorescent Hoechst 33258 stain. Exp Cell Res 104:255-262

26. Lowry OH, Rosebrough NJ, Farr AL, Randall RJ 1951 Protein measurement with the Folin phenol reagent. J Biol Chem 193:265-275

27. Schadewaldt $P$, Wendel U 1987 Comparison of the catabolism of branchedchain L-amino acids in cultured human skin fibroblasts. Pediatr Res 22:591 594

28. Wendel U, Langenbeck U 1984 Intracellular levels and metabolism of leucine and $\alpha$-ketoisocaproate in normal and maple syrup urine disease fibroblasts. Biochem Med 31:294-302

29. Pozefsky T, Walser, M 1977 Effect of intraarterial infusion of the ketoanalogue of leucine on amino acid release by forearm muscle. Metabolism 26:807815

30. Taylor RT, Jenkins WT 1966 Leucine aminotransferase II. Purification and characterization. J Biol Chem 241:4396-4405

31. Meister A 1951 Studies on $d$ - and $l-\alpha$-keto- $\beta$-methylvaleric acids. J Biol Chem 190:269-276

32. Oxender DL, Collarini EJ, Shotwell MA, Lobaton CD, Moreno A, Campbell GS, El-Gewely MA 1986 Cellular transport in the regulation of amino acid metabolism. Biochem Soc Trans (Lond) 14:993-995

33. Schadewaldt P, Radeck W, Staib W 1985 Differential effect of dichloroacetate on branched-chain amino acid catabolism in perfused rat hindlimbs. FEBS Lett 183:33-36

34. Staten MA, Bier DM, Matthews DE 1984 Regulation of valine metabolism in man: a stable isotope study. Am J Clin Nutr 40:1224-1234

35. Walser M, Sapier DG, Mitch WE, Chan W 1981 Effects of branched-chain ketoacids in normal subjects and patients. In: Walser M, Williamson JR (eds) Metabolism and Clinical Implications of Branched Chain Amino and Ketoacids. Elsevier/North-Holland, New York, pp 291-299

36. Wendel U, Langenbeck U, Luthe H, Seakins WT 1986 L-Allo-isoleucine-an inert marker of isoleucine metabolism in maple syrup urine disease. Eur $\mathbf{J}$ Pediatr 144:523

37. Chuang DT, Niu W-L, Cox RP 1981 Activities of branched-chain 2-oxo acid dehydrogenase and its components in skin fibroblasts from normal and classical-maple-syrup-urine-disease subjects. Biochem J 200:59-67

38. Miller RH, Harper AE 1984 Metabolism of valine and 3-methyl-2-oxobutanoate in isolated perfused rat kidney. Biochem J 224:109-116

39. Pettit FH, Yeaman SJ, Reed LJ 1978 Purification and characterization of branched-chain $\alpha$-keto acid dehydrogenase complex of bovine kidney. Proc Natl Acad Sci USA 75:4881-4885

40. Danner DJ, Lemmon SK, Besharse JC, Elsas LJ 1979 Purification and characterization of branched-chain $\alpha$-ketoacid dehydrogenase from bovine liver mitochondria. J Biol Chem 254:5522-5526

41. Parker PJ, Randle PJ 1978 Branched-chain 2-oxo-acid dehydrogenase complex of rat liver. FEBS Lett 90:183-186 